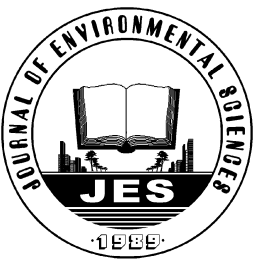

\title{
Soil microbial community structure and function responses to successive planting of Eucalyptus
}

\author{
Falin Chen ${ }^{1}$, Hua Zheng ${ }^{1, *}$, Kai Zhang ${ }^{1}$, Zhiyun Ouyang ${ }^{1}$, \\ Huailin $\mathrm{Li}^{2}$, Bing $\mathrm{Wu}^{2}$, Qian $\mathrm{Shi}^{2}$ \\ 1. State Key Laboratory of Urban and Regional Ecology, Research Center for Eco-Environmental Sciences, \\ Chinese Academy of Sciences, Beijing 100085, China. E-mail: cfl224@163.com \\ 2. Guangxi State Dongmen Forest Farm, Fusui 532108, China
}

Received 28 February 2013; revised 01 April 2013; accepted 11 April 2013

\begin{abstract}
Many studies have shown soil degradation after the conversion of native forests to exotic Eucalyptus plantations. However, few studies have investigated the long-term impacts of short-rotation forestry practices on soil microorganisms. The impacts of Eucalyptus successive rotations on soil microbial communities were evaluated by comparing phospholipid fatty acid (PLFA) abundances, compositions, and enzyme activities of native Pinus massoniana plantations and adjacent 1st, 2nd, 3rd, 4th generation Eucalyptus plantations. The conversion from $P$. massoniana to Eucalyptus plantations significantly decreased soil microbial community size and enzyme activities, and increased microbial physiological stress. However, the PLFA abundances formed " $U$ " shaped quadratic functions with Eucalyptus plantation age. Alternatively, physiological stress biomarkers, the ratios of monounsaturated to saturated fatty acid and Gram+ to Gram- bacteria, formed " $\cap$ " shaped quadratic functions, and the ratio of cy 17:0 to 16:1 $\omega 7 \mathrm{c}$ decreased with plantation age. The activities of phenol oxidase, peroxidase, and acid phosphatase increased with Eucalyptus plantation age, while the cellobiohydrolase activity formed " $U$ " shaped quadratic functions. Soil N:P, alkaline hydrolytic nitrogen, soil organic carbon, and understory cover largely explained the variation in PLFA profiles while soil N:P, alkaline hydrolytic nitrogen, and understory cover explained most of the variability in enzyme activity. In conclusion, soil microbial structure and function under Eucalyptus plantations were strongly impacted by plantation age. Most of the changes could be explained by altered soil resource availability and understory cover associated with successive planting of Eucalyptus. Our results highlight the importance of plantation age for assessing the impacts of plantation conversion as well as the importance of reducing disturbance for plantation management.
\end{abstract}

Key words: phospholipid fatty acid; microbial community structure; soil enzyme activity; Eucalyptus; successive rotation DOI: $10.1016 /$ S1001-0742(12)60319-2

\section{Introduction}

A common global land-use change is the conversion of native forest to fast-growing exotic plantations (Burton et al., 2010; Iovieno et al., 2010) due to increased demand for timber and timber products. However, this form of landuse conversion often exhausts soil nutrients and decreases soil quality (Wei et al., 2009) because of the large demand for nutrients by fast-growing species (Laclau et al., 2010) and forestry-related activities (e.g., weed control, soil preparation, and plantation tending), which consequently influences the sustainability of plantations.

Soil microbial communities may provide early indication of soil changes (Harris, 2009; Banning et al., 2011), and are increasingly used to assess ecosystem responses

\footnotetext{
* Corresponding author. E-mail: zhenghua@ @rcees.ac.cn
}

to environmental perturbations (Harris, 2003; van Dijk et al., 2009; Lewis et al., 2010; Banning et al., 2011) because of its rapid response to anthropogenic disturbances relative to soil biogeochemical properties. These responses have been assessed using soil biological indicators such as the phospholipid fatty acid (PLFA) profiles to reflect the structure of the soil microbial community (Iovieno et al., 2010), and soil enzyme activities to reflect their functional capacity (Rivas et al., 2009). "Signature" PLFA can provide information on specific functional groups of microorganisms present in a community (Frostegård et al., 1993). In an environmental sample, increases in the molar percentages of saturated and cyclopropyl fatty acids and Gram + bacteria are indications of physiological stress or substrate depletion. Microorganisms prefer to use cis-monoenoic fatty acids, likely due to their faster 
turnover rate and ease of metabolism, and this could be a survival mechanism to maintain membrane integrity during starvation (Guckert et al., 1986; Balkwill et al., 1988). In addition, Gram + bacteria thrive under more nutrient-limited environments than Gram- bacteria (Fierer et al., 2003). The composition of PLFA in soil samples has been used to detect sensitive shifts in soil microbial communities due to management and vegetation effects (Bossio and Scow, 1998; Drijber et al., 2000; Hackl et al., 2005; Moore-Kucera and Dick, 2008). The functional capacity of the soil microbial community, as reflected in the activities of the enzymes involved in mineralization processes, also varies among soils dominated by vegetation changes (Waldrop et al., 2000).

Eucalyptus, a fast-growing tree species, has been introduced to many tropical and subtropical regions as an afforestation species (Turnbull, 1999). The short-rotation forestry practices performed in Eucalyptus plantations can be considered representative of most Eucalyptus industrial plantations worldwide. Therefore, afforestation with fastgrowing Eucalyptus has received considerable attention with regard to its impacts on soil properties, which is highly relevant to the sustainable productivity of Eucalyptus plantations. Studies have reported that soil organic carbon, total nitrogen, microbial biomass, and metabolic quotient were significantly lower in Eucalyptus plantations compared with natural and regenerated forests (Behera and Sahani, 2003), native plantations (Chen et al., 2013) or pastures (Sicardi et al., 2004). However, Pulrolnik et al. (2009) found no change in total organic carbon, microbial biomass carbon or nitrogen after the conversion of native savanna to Eucalyptus plantations. A series of studies conducted in Hawaii reported no change in soil carbon after the conversion of sugarcane fields to Eucalyptus plantations, because increased soil carbon caused by Eucalyptus afforestation was offset by the loss of sugarcane-derived carbon (Bashkin and Binkley, 1998; Binkley and Resh, 1999; Binkley et al., 2004). Although the impacts of plantation conversion on soil properties of native ecosystems to Eucalyptus plantation have been well documented, the following two questions remain to be answered: (1) What are the effects of successive planting of Eucalyptus on soil microbial community structure and function after the conversion from native Pinus massoniana to exotic Eucalyptus plantation? (2) Which factors will influence the direction and degree of variation in soil microbial community in Eucalyptus plantations during their shortrotation? In this study, we investigated the variations in soil microbial communities for different-aged Eucalyptus plantations quantified by PLFA abundance, composition, and soil enzyme activities, in Guangxi Province, southern China.

\section{Materials and methods}

\subsection{Study area}

The study sites were located in the Dongmen Forest Farm, Dongmen Town, Fusui County of Guangxi Province $\left(107^{\circ} 47^{\prime}-107^{\circ} 56^{\prime} \mathrm{E}, 22^{\circ} 14^{\prime}-22^{\circ} 21^{\prime} \mathrm{N}\right)$. The mean annual temperature is $21.2-22.3^{\circ} \mathrm{C}$, and the mean annual precipitation is $1100-1300 \mathrm{~mm}$. Soils of the region are mainly lateritic red earths, derived from arenaceous shale, with a typical soil depth of $80 \mathrm{~cm}$ or greater.

In this area, Eucalyptus plantations underwent considerable site preparation and removal of shrubs and weeds prior to reforestation. Special eucalypt fertilizer was applied to promote growth, with $500 \mathrm{~g} /$ plant as base fertilizer (N:P:K $=10: 15: 5)$ at plantation establishment and $250 \mathrm{~g} / \mathrm{plant}$ as supplemental fertilizer (N:P:K = 15:10:8) at 6, 12 and 24 months after plantation establishment.

\subsection{Experimental design and sampling}

We selected four Eucalyptus plantation sites (Eucalyptus urophylla $\times$ grandis) forming a chronosequence of 1 st, 2nd, 3rd, and 4th generation plantations (abbreviated as G1, G2, G3 and G4, respectively) representing plantation ages 3, 8, 14, and 19 years in the Dongmen Forest Farm. Plantation generation refers to the management regime in which Eucalyptus trees were cut every five years and replanted. For example, the 19-year old plantation underwent 4 rotations and was considered 4th generation. Prior to reforestation, all the Eucalyptus plantation sites were native Pinus massoniana plantations, thus one adjacent $P$. massoniana plantation (MP, ca. 20 years) was selected as the standard for comparing native plantation soil properties to non-native. Each site covered an area of approximately 10 ha and all were situated close to each other on a gently sloping area with an elevation approximately $150 \mathrm{~m}$ above sea level.

In October 2010, the top $10 \mathrm{~cm}$ of mineral soil was sampled using a 3.6-cm diameter soil corer. Three $20 \times 20$ $\mathrm{m}^{2}$ plots were established in each plantation. Ten soil cores from random locations in each plot were collected and mixed together as a composite sample. Three composite soil samples were collected at each site, and soil samples were stored on ice for transport to the laboratory. During soil collection, the plant communities were also surveyed. At each site, we identified all tree species within three 20 $\times 20 \mathrm{~m}^{2}$ plots, all shrub species within five $5 \times 5 \mathrm{~m}^{2}$ plots, and all herb species within nine $1 \times 1 \mathrm{~m}^{2}$ plots.

Soil samples were homogenized and sieved $(2 \mathrm{~mm})$ to remove roots and gravel. A portion of soil was immediately frozen at $-20^{\circ} \mathrm{C}$ for subsequent PLFA analysis. Subsamples were air-dried for soil biogeochemical analyses. 


\subsection{Soil physicochemical analysis}

Soil $\mathrm{pH}$ was determined in a 1:2.5 soil-water slurry using a Delta 320 pH meter (Mettler-Toledo Instruments Co., Ltd., China). Soil total $\mathrm{C}$ and total $\mathrm{N}$ were determined by combustion in a Vario EL III Elemental Analyzer (Elementar Analysensysteme GmbH, Germany). Soil organic carbon was measured by wet oxidation using dichromate in acid medium followed by the $\mathrm{FeSO}_{4}$ titration method (Bao, 2000). Alkaline hydrolytic nitrogen was measured using the boric acid absorption - hydrochloric acid titration method (Bao, 2000). Soil was digested using sulfuric acid and perchloric acid and total phosphorus was measured using a Prodigy High Dispersion ICP-OES (Teledyne Technologies Incorporated, USA). Sulfuric acid and hydrochloric acid were used to extract and measure available phosphorus in the soil (Bao, 2000). Available phosphorus was measured using a Prodigy High Dispersion ICP-OES. Fresh soils were analyzed for ammonium $\left(\mathrm{NH}_{4}^{+}-\mathrm{N}\right)$ and nitrate $\left(\mathrm{NO}_{3}^{-}-\mathrm{N}\right)$ using $\mathrm{KCl}$ extraction and a Continuous Flow Analyzer (San++, SKALAR, Netherlands). Table 1 shows the basic characteristics and measured soil properties of the sites.

\subsection{Phospholipid fatty acid analysis}

The biomass and composition of the soil microbial community was measured using PLFA analysis with a modified Buyer method (Buyer et al., 2010). Four grams of lyophilized soil was placed in a $30-\mathrm{mL}$ glass centrifuge tube with a Teflon-lined screw cap. To each soil sample $3.2 \mathrm{~mL}$ of $100 \mathrm{mmol} / \mathrm{L}$ phosphate buffer $(\mathrm{pH} \mathrm{7.4),} 8 \mathrm{~mL}$ of methanol, and $4 \mathrm{~mL}$ of chloroform were added. Tubes were sonicated for $10 \mathrm{~min}$ in a sonicating water bath and then rotated end-over-end for $1 \mathrm{hr}$ at room temperature. After centrifugation for $10 \mathrm{~min}$ at $2500 \mathrm{r} / \mathrm{min}$, the liquid phase was transferred to a $30-\mathrm{mL}$ separatory funnel. Another $3.2 \mathrm{~mL}$ of $100 \mathrm{mmol} / \mathrm{L}$ phosphate buffer and $4 \mathrm{~mL}$ of chloroform were added, shaken vigorously, and allowed to separate overnight. The bottom (organic phase) was evaporated under $\mathrm{N}_{2}$.

Lipid classes were separated by solid phase extraction (SPE) chromatography using a $500 \mathrm{mg}$ silica gel column (Part No. 5982-2265, Agilent Technologies, Wilmington, USA), which was washed with $5 \mathrm{~mL}$ of chloroform in advance. After loading the extract in chloroform, neutral lipids were eluted with $10 \mathrm{~mL}$ of chloroform, polar lipids were eluted with $10 \mathrm{~mL}$ of acetone, and phospholipids were eluted with $5 \mathrm{~mL}$ of methanol. The phospholipid fraction was evaporated under $\mathrm{N}_{2}$.

Fatty acids were trans-esterified with $1 \mathrm{~mL}$ of $1: 1$ methanol:toluene and $1 \mathrm{~mL}$ of $0.2 \mathrm{~mol} / \mathrm{L}$ methanolic $\mathrm{KOH}$ at $35^{\circ} \mathrm{C}$ for $15 \mathrm{~min}$. After adding $2 \mathrm{~mL}$ of a $1: 4$ chloroform:hexane solution, $1 \mathrm{~mL}$ of $1 \mathrm{~mol} / \mathrm{L}$ acetic acid, and $2 \mathrm{~mL}$ of $\mathrm{ddH}_{2} \mathrm{O}$, the mixture was vortexed for $5 \mathrm{~min}$ at $2000 \mathrm{r} / \mathrm{min}$ and the phases allowed to separate. The top phase was removed and the bottom phase was extracted with an additional $2 \mathrm{~mL}$ of 1:4 chloroform:hexane. The combined organic phase was evaporated under $\mathrm{N}_{2}$ and stored at $-20^{\circ} \mathrm{C}$.

The extracts were cleaned by SPE using an $\mathrm{NH}_{2}$ SPE column (Part No. 8B-S009-EAK, Phenomenex, Torrance, CA) washed with $1 \mathrm{~mL}$ of chloroform in advance. Samples were eluted with $1 \mathrm{~mL}$ of chloroform and loaded onto the column. After evaporation under $\mathrm{N}_{2}$, samples were dissolved in $1 \mathrm{~mL}$ of hexane including $10 \mu \mathrm{g} / \mathrm{mL}$ methyl nonadecanoate (19:0) before analysis.

The fatty acid methyl esters were separated on a gas chromatograph with a flame ionization detector (GC-FID) (HP 6890, Agilent Technologies, Santa Clara, USA) using an HP-5 fused silica capillary column $(30 \mathrm{~m} \times 0.25 \mathrm{~mm}$ $\times 0.25 \mu \mathrm{m})$. Helium was used as the carrier gas at 1.0 $\mathrm{mL} / \mathrm{min}$. Splitless injection was employed. Temperature specifications were set to injector temperature $230^{\circ} \mathrm{C}$, detector $270^{\circ} \mathrm{C}$, temperature program: $50^{\circ} \mathrm{C}$ for $1 \mathrm{~min}$, then $15^{\circ} \mathrm{C} / \mathrm{min}$ to $150^{\circ} \mathrm{C}$, maintained for $2 \mathrm{~min}$, and then $3^{\circ} \mathrm{C} / \mathrm{min}$ to $250^{\circ} \mathrm{C}$ with a final hold of $15 \mathrm{~min}$. The individual PLFA peaks were identified by GC-MS (gas chromatograph combined with mass selective detector HP 5973, Agilent Technologies, Santa Clara, USA).

Mass spectrometer peak identification was based on comparison with the spectra of commercially available bacterial methyl ester (BAME) mix standards (Sigma, St Louis, USA) and the software library NIST05.L. The following PLFAs identified bacterial groups: i15:0,

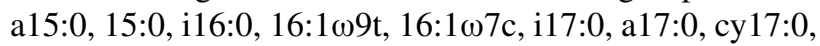

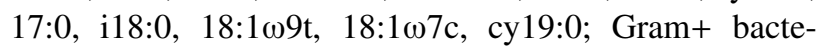
ria: i15:0, i16:0, i17:0, a15:0, a17:0, Gram- bacteria: 16:1 $1 \omega 9 \mathrm{t}, 16: 1 \omega 7 \mathrm{c}, 18: 1 \omega 9 \mathrm{t}, 18: 1 \omega 7 \mathrm{c}$, cy17:0, cy 19:0; fungal groups: $16: 1 \omega 5 \mathrm{c}, 18: 2 \omega 6,9 \mathrm{c}, 18: 1 \omega 9 \mathrm{c}$; actinomycetic groups: 10Me17:0 and 10Me19:0; and 14:0, 16:0, 18:0 were normal PLFAs (Frostegård and Bååth, 1996; Zelles et al., 1997, 1999; Olsson, 1999).

Table 1 Soil characteristics of native P. massoniana plantation, 1st, 2nd, 3rd, and 4th generation Eucalyptus plantations

\begin{tabular}{|c|c|c|c|c|c|c|c|c|c|c|c|}
\hline Stand & Stand age $(\mathrm{yr})$ & $\mathrm{pH}$ & $\mathrm{TN}(\mathrm{g} / \mathrm{kg})$ & $\mathrm{TP}(\mathrm{mg} / \mathrm{kg})$ & $\operatorname{SOC}(\mathrm{g} / \mathrm{kg})$ & $\mathrm{AN}(\mathrm{mg} / \mathrm{kg})$ & $\mathrm{AP}(\mathrm{mg} / \mathrm{kg})$ & $\mathrm{NO}_{3}^{-}-\mathrm{N}(\mathrm{mg} / \mathrm{kg})$ & $\mathrm{NH}_{4}^{+}-\mathrm{N}(\mathrm{mg} / \mathrm{kg})$ & $\mathrm{C}: \mathrm{N}$ & $\mathrm{N}: \mathrm{P}$ \\
\hline MP & $\approx 20$ & $4.21 \pm 0.10$ & $1.64 \pm 0.04 \mathrm{a}$ & $406.89 \pm 1.05 \mathrm{~d}$ & $26.87 \pm 0.39 \mathrm{a}$ & $57.34 \pm 1.54 \mathrm{a}$ & $2.98 \pm 0.11 \mathrm{~b}$ & $2.09 \pm 0.17 \mathrm{a}$ & $12.99 \pm 0.31 \mathrm{a}$ & $19.00 \pm 0.34 \mathrm{a}$ & $4.02 \pm 0.10 \mathrm{a}$ \\
\hline G1 & 3 & $4.28 \pm 0.05$ & $1.01 \pm 0.03 \mathrm{~d}$ & $1067.45 \pm 33.27 \mathrm{ab}$ & $13.35 \pm 0.85 \mathrm{bc}$ & $43.43 \pm 1.60 \mathrm{~b}$ & $5.03 \pm 0.41 \mathrm{a}$ & $0.82 \pm 0.03 b$ & $11.21 \pm 0.20 \mathrm{~b}$ & $15.05 \pm 0.09 \mathrm{~b}$ & $0.95 \pm 0.03 \mathrm{c}$ \\
\hline G2 & 8 & $4.32 \pm 0.10$ & $0.95 \pm 0.02 \mathrm{~d}$ & $896.18 \pm 1.08 \mathrm{c}$ & $10.83 \pm 0.67 \mathrm{c}$ & $41.35 \pm 1.67 \mathrm{~b}$ & $5.14 \pm 0.60 \mathrm{a}$ & $0.54 \pm 0.02 \mathrm{~b}$ & $12.30 \pm 0.43 \mathrm{ab}$ & $13.70 \pm 0.19 \mathrm{c}$ & $1.06 \pm 0.01 \mathrm{c}$ \\
\hline G3 & 14 & $4.24 \pm 0.04$ & $1.31 \pm 0.03 \mathrm{c}$ & $969.37 \pm 5.14 \mathrm{bc}$ & $15.54 \pm 0.20 \mathrm{~b}$ & $60.27 \pm 0.24 \mathrm{a}$ & $2.56 \pm 0.11 \mathrm{~b}$ & $1.80 \pm 0.13 \mathrm{a}$ & $10.63 \pm 0.53 \mathrm{~b}$ & $14.45 \pm 0.09 \mathrm{~b}$ & $1.35 \pm 0.03 \mathrm{~b}$ \\
\hline G4 & 19 & $4.02 \pm 0.03$ & $1.43 \pm 0.05 \mathrm{~b}$ & $1074.81 \pm 33.34 \mathrm{a}$ & $17.17 \pm 0.79 \mathrm{~b}$ & $59.57 \pm 0.61 \mathrm{a}$ & $2.93 \pm 0.10 \mathrm{~b}$ & $1.83 \pm 0.13 \mathrm{a}$ & $11.62 \pm 0.24 \mathrm{ab}$ & $13.38 \pm 0.17 \mathrm{c}$ & $1.33 \pm 0.07 \mathrm{~b}$ \\
\hline$p$-Value & - & NS & $<0.001$ & $<0.001$ & $<0.001$ & $<0.001$ & $<0.01$ & $<0.001$ & $<0.01$ & $<0.001$ & $<0.001$ \\
\hline
\end{tabular}

TN: total nitrogen; TP, total phosphorus; SOC, soil organic carbon; AN, alkaline hydrolytic nitrogen; $\mathrm{AP}$, available phosphorus; $\mathrm{NO}^{-}{ }^{-} \mathrm{N}$ and $\mathrm{NH}_{4}^{+}-\mathrm{N}$, nitrate nitrogen and ammonia nitrogen; $\mathrm{NS}$ : no significance. 


\subsection{Enzyme analysis}

A range of extracellular enzyme activities involved in $\mathrm{C}, \mathrm{N}$, and $\mathrm{P}$ cycling processes was investigated using microplate assays.

Soil $\beta$-glucosidase, phenol oxidase and peroxidase activities were measured according to Sinsabaugh et al. (2003). The substrate for $\beta$-glucosidase assays was $200 \mu \mathrm{mol} / \mathrm{L} p$-nitrophenol (pNP) $\beta$-d-glucopyranoside. The phenol oxidase substrate was $10 \mathrm{mmol} / \mathrm{L} \mathrm{l-}$ dihydroxyphenyalanine (DOPA). The peroxidase substrate was $10 \mathrm{mmol} / \mathrm{L}$ DOPA solution and $0.3 \% \mathrm{H}_{2} \mathrm{O}_{2}$. All substrates were made using $50 \mathrm{mmol} / \mathrm{L} \mathrm{pH} 5.0$ acetate buffer. $5 \mathrm{~g}$ fresh soil was added to $50 \mathrm{~mL}$ of $50 \mathrm{mmol} / \mathrm{L}$ acetate buffer solution ( $\mathrm{pH} 5.0$ ), briefly shaken by hand and stirred on a stir plate for $1 \mathrm{~min}$. Approximately 50 $\mu \mathrm{L}$ of the mixture was added to each lane of a 96-well microplate that contained $150 \mu \mathrm{L}$ of $50 \mathrm{mmol} / \mathrm{L}$ pNPsubstrate solution or acetate buffer (sample control). There were four analytical replicates and four sample controls for each extract. Plates were incubated at $25^{\circ} \mathrm{C}$ for $2 \mathrm{hr}$, then $50 \mu \mathrm{L}$ of the solution in each well was transferred to another 96 -well plate containing $50 \mu \mathrm{L}$ of $1.0 \mathrm{~mol} / \mathrm{L}$ $\mathrm{NaOH}$ solution to terminate the reaction. For phenol oxidase and peroxidase, however, aliquots were transferred to empty wells. Absorbance was measured at $410 \mathrm{~nm}$ for pNP-substrates and at $469 \mathrm{~nm}$ for DOPA assays using a Spectramax plus spectrophotometer. Peroxidase activity was calculated as the difference between samples reacted with and without $\mathrm{H}_{2} \mathrm{O}_{2}$.

Soil cellobiohydrolase activity was measured using the fluorimetric method according to Saiya-Cork et al. (2002). A 50- $\mu \mathrm{L}$ of $200 \mathrm{mmol} / \mathrm{L} 4$-methylumbelliferone$\beta$-D-cellobioside solution was added to each sample well. Blank wells received $50 \mu \mathrm{L}$ of acetate buffer plus $200 \mu \mathrm{L}$ of sample suspension. Negative control wells received 50 $\mu \mathrm{L}$ substrate solution plus $200 \mu \mathrm{L}$ of acetate buffer. Quench standard wells received $50 \mu \mathrm{L}$ of standard $(10 \mathrm{mmol} / \mathrm{L} \mathrm{4-}$ methylumbelliferone) and $200 \mu \mathrm{L}$ of sample suspension. Reference standard wells received $50 \mu \mathrm{L}$ of standard and $200 \mu \mathrm{L}$ of acetate buffer. There were eight replicate wells for each blank, negative control and quench standard. The microplates were incubated in darkness at $25^{\circ} \mathrm{C}$ for 4 hr. To stop the reaction, a $10 \mu \mathrm{L}$ aliquot of $1.0 \mathrm{~mol} / \mathrm{L}$ $\mathrm{NaOH}$ solution was added to each well. Fluorescence was measured using a microplate fluorometer with $365 \mathrm{~nm}$ excitation and $450 \mathrm{~nm}$ emission filters.

Soil protease activity was estimated by determining the amino acids released after incubation of soil with sodium caseinate for $2 \mathrm{hr}$ at $50^{\circ} \mathrm{C}$ using Folin-Ciocalteu reagent according to Ladd and Butler (1972). Soil urease activity was assessed by determining ammonia released after incubation of the soil sample with urea solution for $2 \mathrm{hr}$ at $37^{\circ} \mathrm{C}$, using a UV-1700 spectrophotometer (Shimadzu, Japan) at $\lambda=690 \mathrm{~nm}$ after a 30-min color development period (Kandeler and Gerber, 1988). Soil acid phosphatase activity was measured as for $\beta$-glucosidase, but with substrate pNP-phosphate (Sinsabaugh et al., 2003).

\subsection{Data processing and analysis}

The macro in SigmaPlot 11.0 was used to fit the curve of changes in soil microbial size, structure, and enzyme activity to the different aged Eucalyptus plantations. The composition of the soil microbial community was summarized using principle components analysis on the relative molar percentages of the PLFAs in each sample. The SPSS 16.0 (SPSS Inc., Chicago, IL, USA) software package was employed for the analysis of variance (ANOVA). We analyzed the relationships between environmental variables and the soil microbial community through redundancy analysis. It was performed with CANOCO 4.5. "Species" data was represented by the relative molar percentages of PLFAs or the enzyme activities, which were $\log _{10}(x+1)$ transformed. "Species" data were centered and "environment" data were standardized.

\section{Results}

\subsection{Soil microbial community size}

The soil microbial community size decreased significantly after the plantation conversion from native MP to exotic Eucalyptus plantation $(P<0.05)$, and the stand ages of the Eucalyptus plantation had a substantial effect on PLFA abundance (Fig. 1). All of the measures of PLFA abundance (e.g., single PLFAs, the sum of the abundances of bacterial, fungal, and actinomycetic characteristic PLFAs, and total PLFA) formed " $U$ " shaped quadratic function relationships with stand age of Eucalyptus plantations. The minimum value appeared in the G2 stand (Fig. 1).

\subsection{Soil microbial community structure}

The Eucalyptus plantation age had a significant effect on the PLFA composition of soil microbial communities. Principle component (PC) analysis showed there were significant differences between the microbial PLFA compositions among the different Eucalyptus plantations and MP on PC1 $(P<0.05$, Fig. 2). The axis scores of Eucalyptus plantations on PC1 were quadratic functions of plantation age $\left(y=0.01 x^{2}-0.25 x+0.72, R^{2}=0.8349\right.$, $P<0.001)$, while the axis scores on PC2 decreased with plantation age $\left(y=5.75 \mathrm{e}^{-0.05 x}-3.32, R^{2}=0.9206, P<\right.$ $0.0001)$. The axis scores on PC1 were significantly negative with molar percentages of i15:0, i16:0, i17:0 and 17:0, but were significantly positive with molar percentages of 16:1 $1 \omega 7 \mathrm{c}, 18: 1 \omega 9 \mathrm{t}, 16: 1 \omega 5 \mathrm{c}, 18: 1 \omega 9 \mathrm{c}$ and 10Me17:0). The axis scores on PC2 were significantly negative with molar percentages of cy19:0 and 18:0, but were significantly

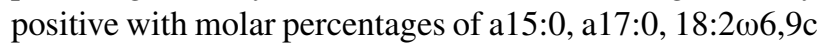
and 16:0 (Fig. 4).

The changes of the above PLFAs led to changes in the ratios of saturated to monounsaturated fatty acid, Gram + to 

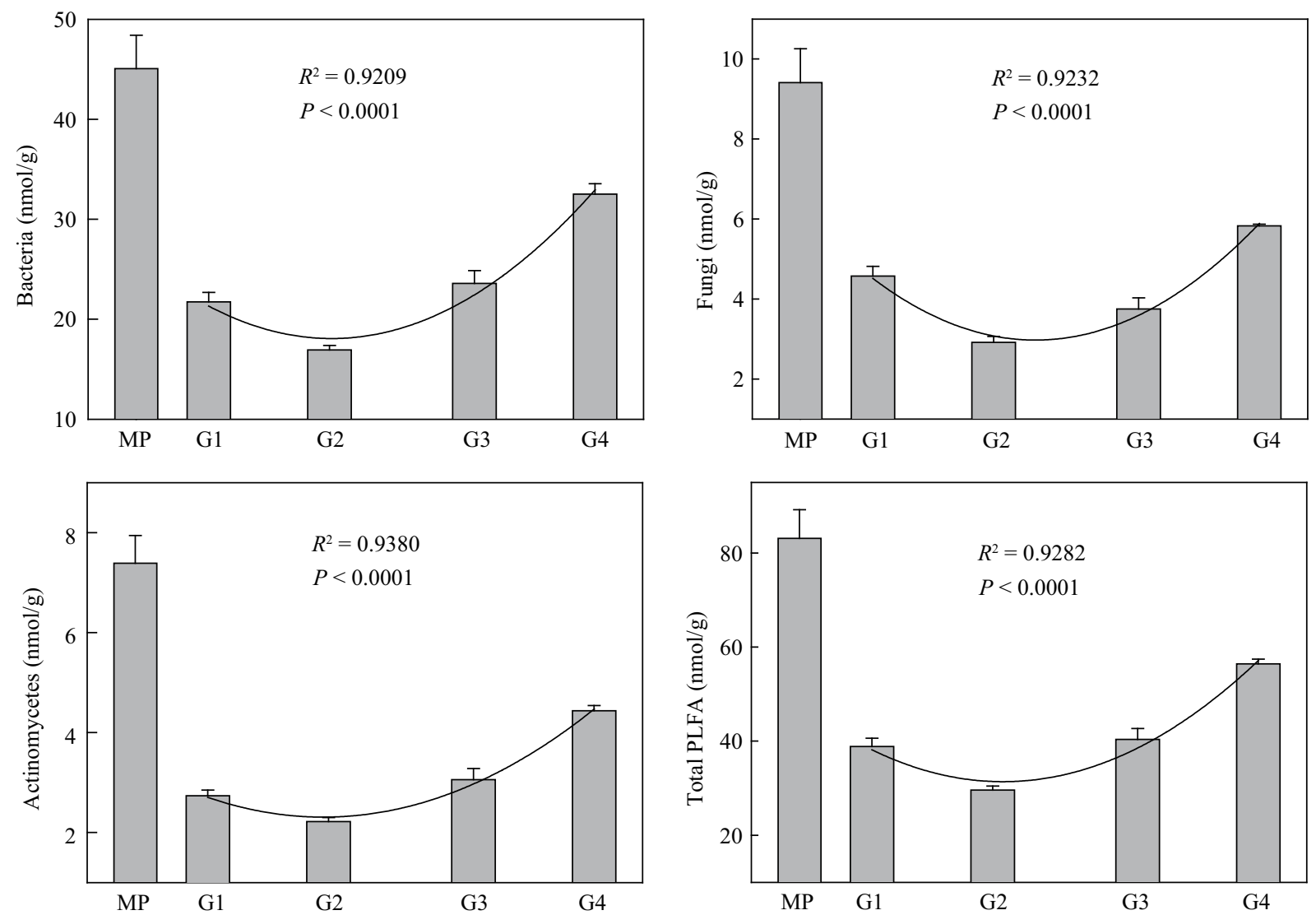

Fig. 1 PLFA abundances in the soils of native P. massoniana plantation (MP), 1st, 2nd, 3rd, and 4th generation Eucalyptus plantations (G1-G4).

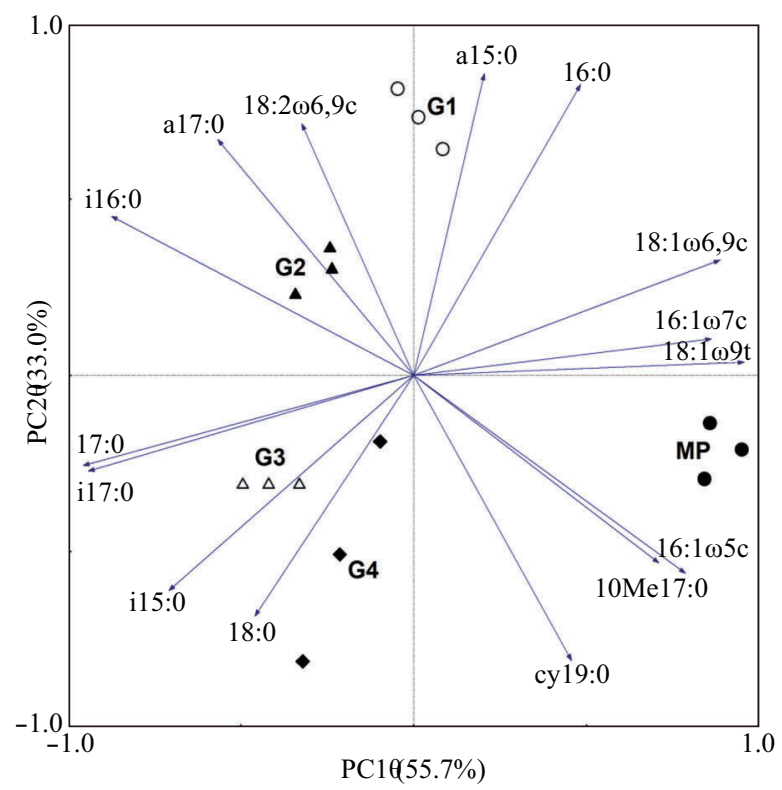

Fig. 2 Principle components (PC) analysis of soil microbial PLFA composition from native P. massoniana plantation (MP), 1st, 2nd, 3rd, and 4th generation Eucalyptus plantations (G1-G4).

Gram- bacteria, and cyclopropyl fatty acid to precursors. The ratios of normal saturated to monounsaturated fatty acids (SAT/MONO), Gram+ to Gram- bacteria (GP/GN),

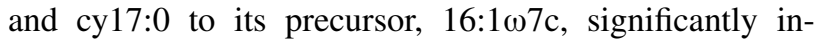
creased after plantation conversion from native MP to Eucalyptus plantations $(P<0.05)$, and they showed significant temporal variations with the Eucalyptus stand age (Fig. 3). SAT/MONO and GP/GN reached maximum at G2 and subsequently slowly decreased with stand age, and were unimodally related to Eucalyptus stand age. The ratio of cy 17:0 to $16: 1 \omega 7 \mathrm{c}$ was an exponential function of Eucalyptus stand age.

\subsection{Soil enzyme activity}

Plantation conversion from native MP to exotic Eucalyptus plantation significantly decreased soil enzyme activities $(P<0.05)$, and the activities of phenol oxidase, peroxidase, cellobiohydrolase and acid soil acid phosphatase showed significant temporal variations with the Eucalyptus stand age (Fig. 4). The activities of phenoloxidase $(P<0.0001)$, peroxidase $(P<0.0001)$ and soil acid phosphatase $(P<0.0001)$ increased gradually with the stand age of the Eucalyptus plantations, while the activities of cellobiohydrolase were " $U$ " shaped quadratic functions $(P<0.01)$, and the minimum value appeared in the G2 stand. There were no significant correlations between the activities of $\beta$-glucosidase, soil protease, soil urease and the Eucalyptus stand age. 

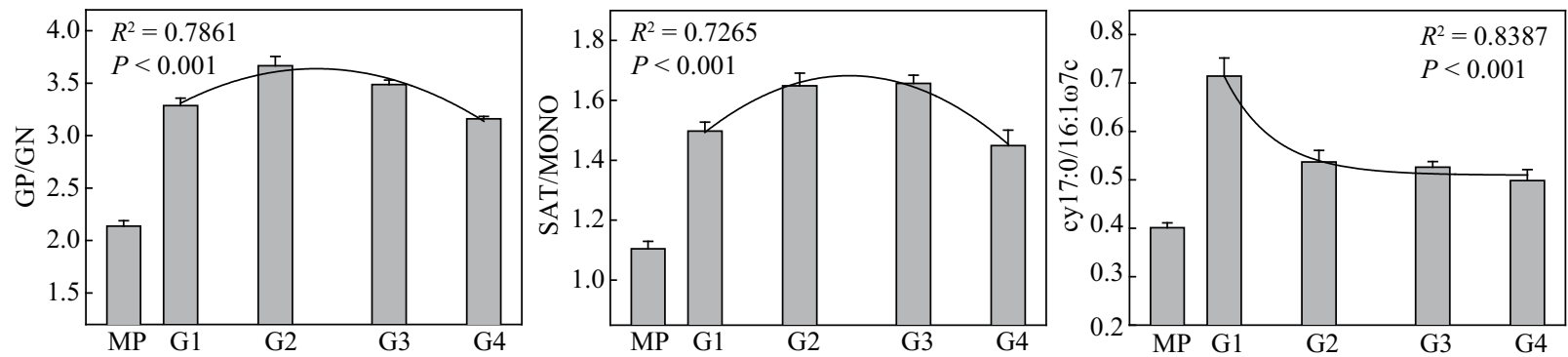

Fig. 3 SAT/MONO ratio of normal saturated to monounsaturated fatty acids and GP/GN ratio of Gram+ to Gram- bacteria.

Table 2 Proportion of microbial community variation explained by significant soil and plant variables based on redundancy analysis in Eucalyptus plantations

\begin{tabular}{llc}
\hline & PLFA & Enzyme activity \\
\hline Soil & & \\
Soil organic carbon & $10.1 \% * *$ & \\
Alkaline hydrolytic nitrogen & $25.6 \% * *$ & $10.2 \% * *$ \\
C:N & $3.9 \%^{*}$ & \\
N:P & $48.0 \% * *$ & $73.7 \% * *$ \\
Plant & $38.6 \% * *$ & $35.7 \% * *$ \\
Understory cover & \multicolumn{2}{l}{$\begin{array}{l} \\
* * * \text { indicate significant differences at } P<0.05 \text { and } P<0.001,\end{array}$} \\
respectively. Blank spaces indicate lack of significant difference.
\end{tabular}

\subsection{Relationships between microbial community com- position, function and environmental factors}

Microbial community composition and its functional capacity could be influenced by aboveground vegetation and soil properties. The soil variables that explained the greatest amount of variation in the PLFA composition were $\mathrm{N}: \mathrm{P}(48.0 \%)$, alkaline hydrolytic nitrogen $(25.6 \%)$, and organic carbon $(10.1 \%)$; for variation in the enzyme activities, the variables were $\mathrm{N}: \mathrm{P}(73.7 \%)$ and alkaline hydrolytic nitrogen $(10.2 \%)$ (Table 2 ). For the plant variables, understory cover explained $38.6 \%$ of the variation in PLFA composition and $35.7 \%$ of the variance in the enzyme activities.

\section{Discussion}

The simultaneous availability of Eucalyptus plantation sites of different stand ages and Pinus massoniana plantation enabled us to apply the 'space-for-time substitution' approach as a surrogate for a long-term study on microbial succession (Pickett 1989; Chauvat et al., 2003). Despite a few methodological shortcomings, this approach is often considered to be the only way of determining long-term changes in forest ecosystems when long-term monitoring datasets of succession are unavailable (Trofymow and Porter, 1998; Chauvat et al., 2003). By using the 'spacefor-time substitution' approach, we found that successive rotations had significant effects on the size, structure, and enzyme activities of soil microbial communities in Eucalyptus plantations after plantation conversion from native Pinus massoniana.
Understanding soil microbial community changes could help to broadly predict how biogeochemical cycles respond to plantation conversion. Previous studies (Sicardi et al., 2004; Berthrong et al., 2009; Chen et al., 2013) have shown that Eucalyptus plantations have significantly different microbial community compositions, smaller sizes and lower functional activities than the soil microbial communities of native species plantations. However, microbial communities recovered with increased stand age of the Eucalyptus plantations (Figs. 1-4). Soil microbial biomass has traditionally been used as an indicator of soil fertility, with decreases indicating a decline in soil quality (Powlson et al., 1987; Wardle, 1992; Zheng et al., 2005). In this study, the PLFA abundances were " $U$ " shaped quadratic functions of the Eucalyptus plantation age (Fig. 1), which indicates that soil fertility recovered gradually after a decrease in the early generation Eucalyptus plantations.

Successive short-rotations of Eucalyptus plantations had a significant effect on the PLFA composition of soil microbial communities (Fig. 2). These changes of PLFA compositions altered the ratios of saturated to monounsaturated fatty acid, Gram+ to Gram- bacteria, and cyclopropyl fatty acid to precursors, which correlate positively with soil nutrient stress or negatively with resource availability (Bossio and Scow, 1998; Fierer et al., 2003; McKinley et al., 2005; Moore-Kucera and Dick, 2008). The ratios of saturated to monounsaturated fatty acid and Gram+ to Gram- bacteria were " $\cap$ " shaped quadratic functions of the Eucalyptus plantation age, and the ratio of cy 17:0 to $16: 1 \omega 7 \mathrm{c}$ decreased gradually with Eucalyptus plantation age (Fig. 3). This suggests that soil resource availability increased gradually after a decrease in the early generation Eucalyptus plantations.

Soil enzymes are directly linked to the turnover rates of organic matter and may provide key insights into the preservation or loss of specific compounds. Soil acid phosphatase may activate phosphorus, which is crucial for improving soil phosphorus availability in this area. Phenol oxidase and peroxidase not only reflect soil quality, but also correspond to the allelochemicals produced by Pinus (Cao et al., 2006) and Eucalyptus (Zhang and Fu, 2009, 2010). Cellobiohydrolase breaks cellulose chains into smaller units, and the enhanced activity of cellobiohydrolase could indicate high litter or root turnover in the soils (Sanaullah et al., 2011). In the study, the activity 

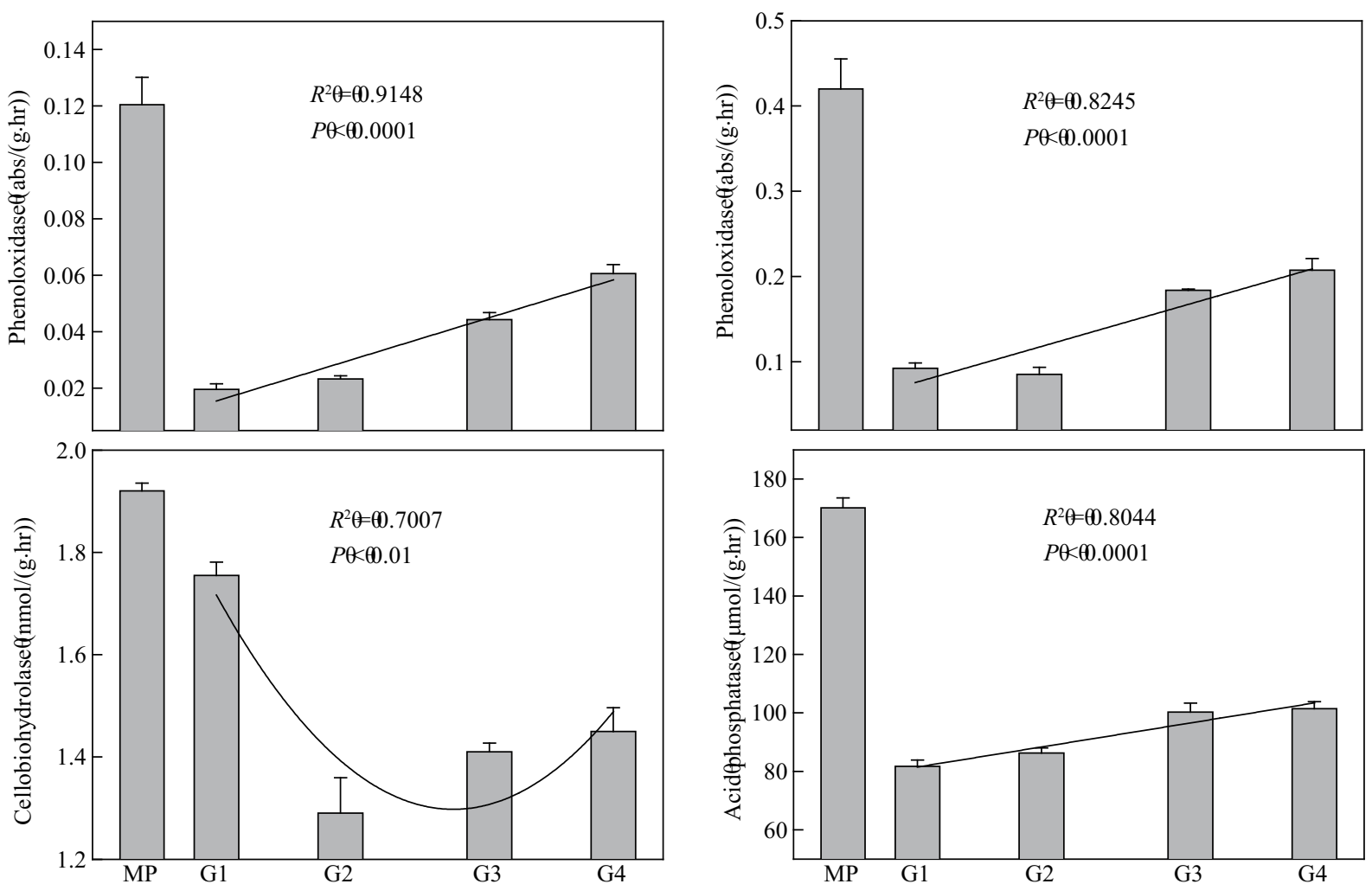

Fig. 4 Soil enzyme activities in native P. massoniana plantation (MP), 1st, 2nd, 3rd, and 4th generation Eucalyptus plantations (G1-G4).

of soil acid phosphatase, phenol oxidase, and peroxidase increased gradually with the stand age of the Eucalyptus plantations. The activities of cellobiohydrolase decreased at first generation and reached their minimum at the 2nd rotation, and subsequently recovered during the 3rd and 4th rotations of Eucalyptus plantations.

The succession of soil microbial community may result from the following factors.

(1) The effects of disturbance on understory vegetation decreased with increases in plantation age. During conversion of Pinus to Eucalyptus plantations, clear-cutting, slash-burning, and plowing destroyed vegetation cover. However, after establishment of Eucalyptus plantations, only smaller disturbances occurred from plowing and tending. Disturbance effects on understory vegetation decreased with time, which would be beneficial to understory vegetation recovery of Eucalyptus plantations (Fig. 5), and thus an improvement in the structure and functional activity of the soil microbial communities (Wu et al., 2011). This may explain why understory plant cover explained the greatest amount of variation in the PLFA composition and enzyme activity (Table 2). Understory species in northern boreal forests have also been shown to drive changes in the soil microbial community (Nilsson and Wardle, 2005).

(2) Improper land management and significant carbon import from Eucalyptus. After the conversion of native P. massoniana plantation to Eucalyptus plantations, artificial tending caused deterioration of the soil structure by breaking up soil macro-aggregates and exposing pre-

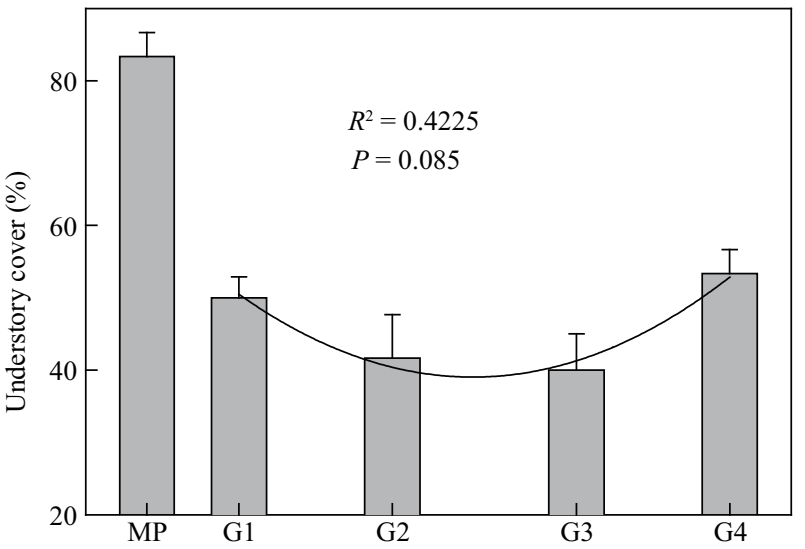

Fig. 5 Understory cover percentage in native P. massoniana plantation (MP), 1st, 2nd, 3rd, and 4th generation Eucalyptus plantations (G1-G4).

viously protected organic matter in the macro-aggregates (Zheng et al., 2005). This may be the main reason for the observed decreases in soil organic matter in 1st and 2nd generation. However, the higher growth rate and water use efficiency of Eucalyptus (Hou, 2006) suggest that Eucalyptus stands fix more plant carbon. This fixed carbon will be transported to the soil through litter fall and root exudates, which will increase soil organic matter with increased time after planting (Lima et al., 2006; Ma et al., 2010). In our study, soil organic carbon formed quadratic functions with Eucalyptus plantation age (Table 1), and partially explained the variation in the PLFA composition and enzyme activity of the soil microbial communities 
(Table 2). The increased organic matter could provide more carbon sources for the soil microbial community and lead to eventual recovery of the structure and activities of the soil microbial community.

(3) Fertilization compensates for the losses of $\mathrm{N}$ and $\mathrm{P}$ caused by Eucalyptus uptake. The high nutrient demands of Eucalyptus lead to higher losses of nutrients in Eucalyptus plantations compared to native Pinus (Laclau et al., 2003), thereby causing decreases in soil resource availability, as indicated by the lower soil N:P, and alkalihydrolysable N (Table 1). However, fertilization was used in the first two years after Eucalyptus planting, which could in part lead to increases in soil N:P, and alkalihydrolysable $\mathrm{N}$ with successive rotations of Eucalyptus plantations. This may explain why soil N:P and alkalihydrolysable $\mathrm{N}$ explained the greatest amount of variation in the PLFA composition and enzyme activity.

\section{Conclusions}

The Eucalyptus plantations compared to the native $P$. massoniana plantation had significantly different microbial community compositions, and had smaller sizes and reduced functional activities of soil microbial communities. Successive short-rotations of Eucalyptus plantations after plantation conversion from native Pinus massoniana had significant impacts on the soil microbial community. The size, structure, and function of the soil microbial community recovered with the stand age of Eucalyptus plantations. The responses of soil microbial communities are likely regulated by the availability of soil resources and the effects of successive rotations on understory communities. In the long run, understory conservation and reduction of soil disturbance during plantation management could contribute to the recovery of soil microbial structure and function. Our results also highlight the importance of plantation age for assessing the impacts of plantation conversion, as well as the importance of reducing disturbance for plantation management.

\section{Acknowledgments}

This work was supported by the Knowledge Innovation Program of the Chinese Academy of Science (No. KZCX2-EW-QN406) and the National Natural Science Foundation of China (No. 31170425, 40871130). We thank Prof. Qingbiao Wu, Fuyan Wei, and Xiangguang Pan for the field research. We also appreciate the anonymous reviewers for their constructive suggestions and Christina Wong for language editing.

\section{References}

Balkwill D L, Leach F R, Wilson J T, McNabb J F, White D C, 1988. Equivalence of microbial biomass measures based on membrane lipid and cell-wall components, adenosine triphosphate, and direct counts in subsurface aquifer sediments. Microbial Ecology, 16(1): 73-84.

Banning N C, Gleeson D B, Grigg A H, Grant C D, Andersen G L, Brodie E L et al., 2011. Soil microbial community successional patterns during forest ecosystem restoration. Applied and Environmental Microbiology, 77(17): 61586164.

Bao S D, 2000. Soil and Agricultural Chemistry Analysis (3rd ed.). China Agriculture Press, Beijing.

Bashkin M A, Binkley D, 1998. Changes in soil carbon following afforestation in Hawaii. Ecology, 79(3): 828-833.

Behera N, Sahani U, 2003. Soil microbial biomass and activity in response to Eucalyptus plantation and natural regeneration on tropical soil. Forest Ecology and Management, 174(1-3): $1-11$.

Berthrong S T, Schadt C W, Pineiro G, Jackson R B, 2009. Afforestation alters the composition of functional genes in soil and biogeochemical processes in south american grasslands. Applied and Environmental Microbiology, 75(19): 6240-6248.

Binkley D, Kaye J, Barry M, Ryan M G, 2004. First-rotation changes in soil carbon and nitrogen in a Eucalyptus plantation in Hawaii. Soil Science Society of America Journal, 68(5): 1713-1719.

Binkley D, Resh S C, 1999. Rapid changes in soils following eucalyptus afforestation in Hawaii. Soil Science Society of America Journal, 63(1): 222-225.

Bossio D A, Scow K M, 1998. Impacts of carbon and flooding on soil microbial communities: Phospholipid fatty acid profiles and substrate utilization patterns. Microbial Ecology, 35(3): 265-278.

Burton J, Chen C G, Xu Z H, Ghadiri H, 2010. Soil microbial biomass, activity and community composition in adjacent native and plantation forests of subtropical Australia. Journal of Soils and Sediments, 10(7): 1267-1277.

Buyer J S, Teasdale J R, Roberts D P, Zasada I A, Maul J E, 2010. Factors affecting soil microbial community structure in tomato cropping systems. Soil Biology and Biochemistry, 42(5): 831-841.

Cao G Q, Lin S Z, Hu Z Q, Wang A P, Peng Y R, 2006. Bio-detection and identification of biochemical substances in Pinus massoniana leaves. Acta Botanica BorealiOccidentalia Sinica, 26(4): 811-818.

Chauvat M, Zaitsev A S, Wolters V, 2003. Successional changes of Collembola and soil microbiota during forest rotation. Oecologia, 137(2): 269-276.

Chen F, Zheng H, Zhang K, Ouyang Z Y, Lan J, Li H L et al., 2013. Changes in soil microbial community structure and metabolic activity following conversion from native Pinus massoniana plantations to exotic Eucalyptus plantations. Forest Ecology and Management, 291: 65-72.

Drijber R A, Doran J W, Parkhurst A M, Lyon D J, 2000. Changes in soil microbial community structure with tillage under long-term wheat-fallow management. Soil Biology and Biochemistry, 32(10): 1419-1430.

Fierer N, Schimel J P, Holden P A, 2003. Variations in microbial community composition through two soil depth profiles. Soil Biology and Biochemistry, 35(1): 167-176.

Frostegård A, Bååth E, 1996. The use of phospholipid fatty acid analysis to estimate bacterial and fungal biomass in soil. 
Biology and Fertility of Soils, 22(1-2): 59-65.

Frostegård A, Bååth E, Tunlid A, 1993. Shifts in the structure of soil microbial communities in limed forests as revealed by phospholipid fatty acid analysis. Soil Biology and Biochemistry, 25(6): 723-730.

Guckert J B, Hood M A, White D C, 1986. Phospholipid esterlinked fatty acid profile changes during nutrient deprivation of vibrio cholerae: increases in the trans/cis ratio and proportions of cyclopropyl fatty acids. Applied and Environmental Microbiology, 52(4): 794-801.

Hackl E, Pfeffer M, Donat C, Bachmann G, ZechmeisterBoltenstern S, 2005. Composition of the microbial communities in the mineral soil under different types of natural forest. Soil Biology and Biochemistry, 37(4): 661-671.

Harris J A, 2003. Measurements of the soil microbial community for estimating the success of restoration. European Journal of Soil Science, 54(4): 801-808.

Harris J, 2009. Soil microbial communities and restoration ecology: facilitators or followers? Science, 325(5940): 573-574.

Hou Y, 2006. Understanding scientifically the issue of developing fast-growing and high-yielding eucalypt plantation in South China. World Forestry Research, 19(3): 71-76.

Iovieno P, Alfani A, Bååth E, 2010. Soil microbial community structure and biomass as affected by Pinus pinea plantation in two Mediterranean areas. Applied Soil Ecology, 45(1): 56-63.

Kandeler E, Gerber H, 1988. Short-term assay of soil urease activity using colorimetric determination of ammonium. Biology and Fertility of Soils, 6(1): 68-72.

Laclau J P, Deleporte P, Ranger J, Bouilleti J P, Kazotti G, 2003. Nutrient dynamics throughout the rotation of Eucalyptus clonal stands in Congo. Annals of Botany, 91(7): 879-892.

Laclau J P, Ranger J, de Moraes Gonçalves J L, Maquère V, Krusche A V, M'Bou A T et al., 2010. Biogeochemical cycles of nutrients in tropical Eucalyptus plantations: Main features shown by intensive monitoring in Congo and Brazil. Forest Ecology and Management, 259(9): 17711785.

Ladd J N, Butler J H A, 1972. Short-term assays of soil proteolytic enzyme activities using proteins and dipeptide derivatives as substrates. Soil Biology and Biochemistry, 4(1): 19-30.

Lewis D E, White J R, Wafula D, Athar R, Dickerson T, Williams $\mathrm{H} \mathrm{N}$ et al., 2010. Soil functional diversity analysis of a bauxite-mined restoration chronosequence. Microbial Ecology, 59(4): 710-723.

Lima A M N, Silva I R, Neves J C L, Novais R F, Barros N F, Mendonca E S et al., 2006. Soil organic carbon dynamics following afforestation of degraded pastures with Eucalyptus in southeastern Brazil. Forest Ecology and Management, 235(1-3): 219-231.

Ma X X, Gong W, Hu T X, Wang J Y, Li X P, Shi W, 2010 Effects of conversion of natural forest and slope farmland to Eucalyptus grandis plantation on soil nutrients. Journal of Sichuan Agricultural University, 28(1): 56-60.

McKinley V L, Peacock A D, White D C, 2005. Microbial community PLFA and PHB responses to ecosystem restoration in tallgrass prairie soils. Soil Biology and Biochemistry, 37(10): 1946-1958.

Moore-Kucera J, Dick R P, 2008. PLFA profiling of microbial community structure and seasonal shifts in soils of a Douglas-fir chronosequence. Microbial Ecology, 55(3): 500-511.

Nilsson M C, Wardle D A, 2005. Understory vegetation as a forest ecosystem driver: evidence from the northern Swedish boreal forest. Frontiers in Ecology and the Environment, 3(8): 421-428.

Olsson P A, 1999. Signature fatty acids provide tools for determination of the distribution and interactions of mycorrhizal fungi in soil. FEMS Microbiology Ecology, 29(4): 303-310.

Pickett S T A, 1989. Space-for-time substitution as an alternative to long-term studies. In: Long-term Studies in Ecology (Likens G E, eds.). Springer, Berlin Heidelberg, New York. 110-135.

Powlson D S, Brookes P C, Christensen B T, 1987. Measurement of soil microbial biomass provides an early indication of changes in total soil organic matter due to straw incorporation. Soil Biology and Biochemistry, 19(2): 159-164.

Pulrolnik K, de Barros N F, Silva I R, Novais R F, Brandani C $\mathrm{B}, 2009$. Carbon and nitrogen pools in soil organic matter under eucalypt, pasture and savanna vegetation in Brazil. Revista Brasileira De Ciencia Do Solo, 33(5): 1125-1136.

Rivas Y, Oyarzun C, Godoy R, Valenzuela E, 2009. Nitrogen and carbon mineralization and enzyme activity in soils of Nothofagus obliqua (Mirb) Oerst stands and Pinus radiata D. Don plantation in south-central Chile. Revista Chilena de Historia Natural, 82(1): 119-134.

Saiya-Cork K R, Sinsabaugh R L, Zak D R, 2002. The effects of long term nitrogen deposition on extracellular enzyme activity in an Acer saccharum forest soil. Soil Biology and Biochemistry, 34(9): 1309-1315.

Sanaullah M, Blagodatskaya E, Chabbi A, Rumpel C, Kuzyakov Y, 2011. Drought effects on microbial biomass and enzyme activities in the rhizosphere of grasses depend on plant community composition. Applied Soil Ecology, 48(1): 3844.

Sicardi M, García-Prechac F, Frioni L, 2004. Soil microbial indicators sensitive to land use conversion from pastures to commercial Eucalyptus grandis (Hill ex Maiden) plantations in Uruguay. Applied Soil Ecology, 27(2): 125-133.

Sinsabaugh R L, Saiya-Corka K, Long T, Osgood M P, Neher D A, Zak D R et al., 2003. Soil microbial activity in a Liquidambar plantation unresponsive to $\mathrm{CO}_{2}$-driven increases in primary production. Applied Soil Ecology, 24(3): 263271.

Trofymow J A, Porter G L, 1998. Introduction to the coastal forest chronosequence project. In: Proceedings of a Workshop on Structure, Process, and Diversity in Successional Forests of Coastal British Columbia, Victoria, British Columbia (Trofymow J A, MacKinnon A, eds.). Northwest Science Vol. 72. Washington State University Press, Washington. 48 .

Turnbull J W, 1999. Eucalypt plantations. New Forests, 17(1-3): $37-52$.

van Dijk J, Didden W A M, Kuenen F, van Bodegom P M, Verhoef H A, Aerts R, 2009. Can differences in soil community composition after peat meadow restoration lead to different decomposition and mineralization rates? Soil Biology and Biochemistry, 41(8): 1717-1725.

Waldrop M P, Balser T C, Firestone M K, 2000. Linking microbial community composition to function in a tropical 
soil. Soil Biology and Biochemistry, 32(13): 1837-1846.

Wardle D A, 1992. A comparative assessment of factors which influence microbial biomass carbon and nitrogen levels in soil. Biological Reviews of the Cambridge Philosophical Society, 67(3): 321-358.

Wei Y C, Ouyang Z Y, Miao H, Zheng H, 2009. Exotic Pinus carbaea causes soil quality to deteriorate on former abandoned land compared to an indigenous Podocarpus plantation in the tropical forest area of southern China. Journal of Forest Research, 14(4): 221-228.

Wu J P, Liu Z F, Wang X L, Sun Y X, Zhou L X, Lin Y B et al., 2011. Effects of understory removal and tree girdling on soil microbial community composition and litter decomposition in two Eucalyptus plantations in South China. Functional Ecology, 25(4): 921-931.

Zelles L, 1997. Phospholipid fatty acid profiles in selected members of soil microbial communities. Chemosphere, 35(1-2): 275-294.

Zelles L, 1999. Fatty acid patterns of phospholipids and lipopolysaccharides in the characterisation of microbial communities in soil: A review. Biology and Fertility of Soils, 29(2): 111-129.

Zelles L, Palojärvi A, Kandeler E, VonLützow M, Winter K, Bai Q Y, 1997. Changes in soil microbial properties and phospholipid fatty acid fractions after chloroform fumigation. Soil Biology and Biochemistry, 29(9-10): 1325-1336.

Zhang C L, Fu S L, 2009. Allelopathic effects of Eucalyptus and the establishment of mixed stands of Eucalyptus and native species. Forest Ecology and Management, 258(7): 13911396.

Zhang C L, Fu S L, 2010. Allelopathic effects of leaf litter and live roots exudates of Eucalyptus species on crops. Allelopathy Journal, 26(1): 91-99.

Zheng H, Ouyang Z Y, Wang X K, Fang Z G, Zhao T Q, Miao H, 2005. Effects of regenerating forest cover on soil microbial communities: A case study in hilly red soil region, Southern China. Forest Ecology and Management, 217(2-3): 244254. 